http://www.historycooperative.org/journals/lhr/22.3/comment_getzler.html

From the Law and History Review Vol. 22, Issue 3.

Viewed January 3, 2012 18:19 EST

Presented online in association with the History Cooperative. http://www.historycooperative.org

FORUM: COMMENT

\title{
Chancery Reform and Law Reform
}

\author{
Joshua Getzler
}

Michael Lobban shows how dissatisfaction with the law-equity split in English civil justice predated the Judicature Act reforms by two generations at least (one could argue two-and-a half centuries or more- periodization fails quickly). ${ }^{1}$ Lobban links the first modern debates over fusion to high legal politics on the one hand and to the more intricate internal problems of evidence, procedure, and jurisdiction on the other. Lawyers of the earlier Victorian age found the Chancery system bequeathed to them by Lord Eldon to be intolerable on two counts: it represented Old Corruption or monopolistic private control of public offices and it exacted heavy costs in procedural inconvenience, cost, and delay. Lobban does not see ideology such as Benthamite philosophy driving the rationalization of Chancery doctrine and institutions though he does not dismiss this factor entirely.

Lobban has elsewhere written with great authority both on the politics of law reform and on interactions between law and equity in contract and company law both before and after the 1873 reforms. It is significant that he does not explore doctrinal conflict in his history of earlier fusion, choosing instead to focus on general jurisdictional and procedural politics. He includes meticulous statistical work concerning the caseload of the Chancery and its failure to deliver necessary legal services.

The key parts of Lobban's narrative and arguments may be restated and glossed as follows. From Lord Eldon's time Chancery had become mired in delay and marred by the blatant profit seeking of its officials. At the same time Chancery procedures were becoming more important in the legal regulation of the modernizing commercial economy with its larger-scale firms, elaborate credit structures, and increased incidence of insolvency. Chancery was important because (unlike the common law) it could handle multipartite suits, it could administer accounts and declare rights and duties in the fiduciary economy, and it could supervise remedies. Perhaps its trump card in attracting business was its relatively free admission of evidence including testimony from witness parties and extensive use of pretrial discovery and written bills. ${ }^{2}$ Another striking distinction between equitable and common law procedure was that in Chancery there was no lay jury serving as trier of fact and requiring instruction and control by the judge. 
Lobban shows that earlier reform proposals tended to be debated in party-political terms concerning the competence of the tiny number of Chancery judges in dealing with their caseload and the need for more judges able to concentrate on judicial business as opposed to the distracted Lord Chancellor who had to discharge political as well as legal roles. These criticisms led to the solution of cross-blending of jurisdictions rather than rationalizing of the adjectival and substantive law administered by the judges. The modest intellectual ambitions of the 1873-75 reforms derived from the limited fusionary experiments of earlier decades. It was law reform of, for, and by legal professionals and hence constrained by professional self-interest. Thus the bifurcated law-equity system could survive the Judicature Act reforms in a new guise.

It is important to resist any representation of law reform debates at this time as purely party political or ideological in nature. Partisan debate over Chancery there certainly could be: the leading Tory politician and Chancery silk Edward Sugden (later to end up on the Woolsack as Lord St. Leonards) constantly criticized the reforms proposed by Brougham. Indeed Sugden is portrayed by Lobban as the ultimate insider defending a privileged but moribund system against Whig reformers. Yet there is more to tell of this key figure of Chancery law and politics. His many policy shifts can be explained in light of his personal rivalries with Brougham and Campbell and also his experience as a judge in Ireland. Sugden's fertile period of work as Irish Lord Chancellor (1834-35 and 184146) proved to be a trailblazer for his later reformist career as Lord Chancellor for England (1856-58) and afterward during his time as an active legal peer. His reform proposals of the early 1830s as Member of Parliament and (briefly) as Solicitor-General certainly influenced Brougham's own program. Lobban focuses on only the most prominent example of Sugden's work when he adopted the Whig Chancery Commission's recommendations and retired the masters, paying out their sinecurist offices. Yet Sugden also radically simplified testamentary procedures and mechanisms for the enforcement of judgments; and he was personally committed to alleviating imprisonment for debt and opening access to justice for the poor. This was not exactly the behavior of a reactionary follower of Eldon. Sugden in later career had a characteristically unseemly spat with Sir John Romilly over who had thought up the various judicial reforms of the 1830s and 1840 s in the first place; Sugden wanted to claim the intellectual paternity. The simple explanation of Sugden's reformist motives - and of Brougham and many other actors in this drama-is careerism. Sugden supported reform measures that he himself had proposed and blocked those emanating from his rivals such as Romilly, Campbell, Brougham, and later Hatherley; advancing his own star was Sugden's main preoccupation as it has been for many ambitious lawyers before and since.

Brougham at one stage toyed with the idea of separating the judicial role of the Lord Chancellorship from the political role and considered buying off Sugden with judicial office as part of the plan. We may doubt whether Brougham really believed in the separation of the legal and political roles outside tactical motives of expedience, as Lobban indeed intimates. On the other hand there may be a large if tacit constitutional issue in play here. John Langbein has suggested that in earlier times there was a "single chancellor rule," whereby the free-wheeling jurisdiction of the Lord Chancellor had to be controlled by making him answerable politically to the Parliament and the Executive; hence it was important that he belong to both arms of government. To have a corps of Chancery judges qua lawyers without political responsibility would have undermined this political control. This idea inverts separation of powers doctrine; it regards fusion of judicial and governmental power as a curb on abuse of judicial authority. Moreover, and somewhat paradoxically, the fusion of law and administration seemed to strengthen the 
Bench's power to resist political pressures by affording the judges a voice in political life. It would be interesting to further pursue the attenuated nature of separation of powers doctrines in England in the mid-nineteenth century. Clues might be found by investigating security of judicial tenure and the politics of judicial promotion at this time. The resonances of this history with today's debates over judicial independence are stronger than ever.

We may add a further dimension to the political and institutional story told by Lobban, namely that of a Chancery professional identity, even an equity lawyer's mentalité. Let us take some slightly late evidence of the phenomenon. In a letter to M. M. Bigelow in 1906, over thirty years after the union of legal and equitable jurisdictions in the wake of the Judicature Acts, F. W. Maitland wrote:

Do you ever regret the whole equitable development? I sometimes do ... at times I hate Equity and think of her as a short sighted busybody. Yet I was bred in Equity chambers and used to despise the common lawyer as an inferior person..$^{-}$

These casual lines from Maitland's pen are highly revealing, exposing the split personality of English private lawyers that ran deep in the nineteenth century and that continues to inform modern English and Commonwealth jurisprudence. Patrick Polden has shown how the courts from the time of the 1852 Common Law Procedure Act could have made extensive fusionary experiments at least with private law remedies - but refused to do so. ${ }^{4}$ Lord Selborne and Lord Cairns, the authors of the Judicature Acts, believed that all sense of a separate Chancery jurisdiction would quickly melt away within a fused system, but their legal peers falsified their hopes. It is an interesting question to ask why this was soLobban clearly identifies this key legal-historical problem in his conclusion but ultimately only manages to restate the problem, observing that the different cultures and traditions of law and equity survived and even deepened after fusion.

There were at least three barriers to the fusion of law and equity in the nineteenth century. First there was the inertial weight of the existing divided institutions of civil jurisdiction, requiring an enormous input of law reformers' energy to effect change. Adding to this was the power of interest groups who depended on the continued existence of a separate equity jurisdiction for income, including not only cash incomes but the psychic and social esteem that came from a specialist professional career. And growing from identity was the matter of ideology, which had an interior and exterior dimension. Chancery interpretation of legal phenomena was expressed through the language of equitable conscience and good faith, and a concomitant obsession with fraud. This attitude was shaped by the Chancery's Romanist- and canon-influenced free evidence rules and its strong in personam array of remedies, in the special sense of jurisdiction over the conscience and the body, not just the purse or possessions, of litigants. Alongside that internal style there was an outward-facing Chancery ideology that sought to protect both "old property" interests and weak or vulnerable parties from the corrosive impact of market rationality. We will return to the paternalism of equity in a moment.

One of Lobban's major insights is to explore the working context of Chancery mentality and ideology. He shows how the burgeoning English commercial economy badly needed the premodern equitable procedures, doctrines, and remedies, yet could not make the antiquated system of an independent equity jurisdiction work effectively. But this insight leads to another question. If equity was a necessary gloss on the law, what then was happening in the dominant legal system at this time that led to so much pressure on the supplementary Chancery court? What was the nature of the legal "text" that needed equitable glossing? Chancery reform cannot be examined in isolation, as Lobban has himself shown. 
A major reason for Chancery's near collapse, as it grappled with the legal needs of nineteenth-century commercial society, was its absorption under Lord Eldon of almost the entire bankruptcy jurisdiction from the discredited bankruptcy commissioners. The results of this takeover were mostly unhappy, as countless well-informed contemporaries noted. The origin of the problem lay in the nature of the commissioners for bankruptcy, tribunals of lawyers and merchants dating from a statute of 1571 with a range of ill-defined powers to administer bankruptcy proceedings. The commissioners won an infamous reputation for being venal, vicious, and incompetent. In 1818 the Select Committee on Bankruptcy Laws found the proceedings of the London commissioners for bankruptcy "the worst constituted court of justice that can be imagined." ${ }^{5}$ Judicial guidance of the bankruptcy jurisdiction through legal control of the bankruptcy commissioners was commonly regarded as haphazard and unpredictable. Before 1732 legal matters were referred to the law courts in an ad hoc fashion, and only after a reforming statute in 1732 was the Lord Chancellor given a strong supervisory power over bankruptcy jurisdiction. Lord Hardwicke (Lord Chancellor between 1737 and 1757) strove to regularize the jurisdiction but stable legal rules failed to emerge; it was said that the commissioners were incapable of following rules or precedents. Judges themselves could also be anarchic; for example, in 1798 Lord Kenyon ignored a mass of contrary case authority to hold that criminal mens rea was essential to find an act of bankruptcy, throwing the entire bankruptcy jurisdiction of courts and commissioners into disarray. The legislature finally intervened with a thorough consolidation and reform of bankruptcy law in 1825, , followed by further rafts of legislation throughout the nineteenth century. Lord Eldon himself in a moment of reflection stated in $1801^{7}$ that Chancery supervision of bankruptcy was so inadequate that his court had helped promote "as great a nuisance as any known in the land." This inadequate supervision was continued because it was so very lucrative for Chancery judges and officials, but it was an extremely time-consuming business for the court and its other business suffered.

Bankruptcy gravitated to Chancery partly because of the advantages of its account procedures. As Lobban notes, the corruption and abuses of the masters and clerks of Chancery meant that the critically important system for taking of accounts was dilatory and expensive. Account indeed had a significance far wider than the administration of insolvent individuals or firms. Account as a form of action was an adjectival rather than a substantive institution, being the process by which a person charged with fiduciary management of another's affairs must state all receipts and outgoings and bring the balance to its just point of discharge. This arcane process, run by the notorious Masters' Office, was the essential device for regulating fiduciary management of inter vivos and testamentary trusts, partnerships, companies, agencies, estates in bankruptcy, and indeed profit taking in wide contexts of intellectual property and contract.

The key paradox of Chancery was that its strengths in pretrial procedure, in examination of witnesses, in taking of accounts, in enforcement of remedies and so on, also constituted weaknesses as these equitable procedures were so slow and expensive to run. Lobban suggests that reformers concentrated on perfecting the machinery for delivery of these legal services but were unable to achieve great success because of entrenched interests. We might ask an alternative question: if Chancery was unreformable, why, then, did not the other major law-making agencies - the courts of common law and the Parliament - act to provide substitutes rather than depend on an inadequate Chancery? One answer is that attempts were indeed made in these fori. Many examples can be adduced; we will start with legislation. The saga of legislative bankruptcy reform has already been mentioned. Also significant is the move into legislatively authorized 
corporate law, which may be seen as an attempt by entrepreneurs to avail themselves of more efficient legal structures than the workable but limited forms of agency, trust, and partnership that fell to be regulated in Chancery. It is important to note that the shift to a corporate economy came well after the first two waves of modern industrialization (textiles and light manufacture in the later eighteenth and early nineteenth century, heavier industry and transportation in the 1830s and 1840s) and were not driven by the determinations of industrial capitalism, at least not by a simple linear causation. Rather the limiting nature of the legal system seems to be a dominant factor in explaining the rush to incorporation after the 1840s. The major reforms of local, magisterial, and coroners' jurisdictions in the late 1840s, led by Sir John Jervis, is also of great significance in understanding the context within which mid-century equity operated. The professionalization and juridification of the local courts was done in an entirely pragmatic, un-Benthamic mood, but it possibly affected the administration of justice more than any other measure. At a higher level of governance we may observe the dominant role of local and personal acts in regulating the expanding economy; in the railway age perhaps the bulk of practice of the London bar was not at the Westminster courts of law, but rather in Parliament itself, drafting legislation and representing parties affected by legislation before committees. This was the prime legal arena where the entrepreneurial classes negotiated changes to property rights and set up ad hoc systems for the licensing of enterprise and the regulation of markets, utilities, and municipal government. The shifting of the legal business of the Age of Progress into new jurisdictions outside the conventional law and equity courts adds an essential dimension to the fusion story.

Chancery's intrinsic jurisdiction to protect the vulnerable grew to embrace lunatics, children, women, sailors, expectant heirs, and other parties regarded as incapable of contracting rationally. Beyond these protected classes we may locate in similar vein Chancery's protection of copyholders, charitable purposes, and indeed cestuis que trust and beneficiaries of fiduciary relationships generally. It has been argued by Horwitz and Atiyah that this paternalistic system of intervention was challenged by political economy and libertarianism on the bench in the mid-nineteenth century, though their proof texts were limited. It would be interesting to revisit the "rise of freedom of contract" thesis viewed through the lens of fusionary reform.

It is also necessary to reassess Chancery regulation of married women's property, contractual capacity, and status under coverture in the light of the major Victorian redrawing of family status law in mid-century. This issue may be joined to the decline of ecclesiastical jurisdiction over family law in the mid-nineteenth century and the establishment of the new probate and divorce court in 1858 with Sir Cresswell Creswell presiding over the divorce jurisdiction.

The reform of family law shows how Victorian reformers might develop public law solutions rather than rely on improving mechanisms for private persons to seek remedies in the courts. This is the era of the rise of "officialism" or state-led coordination and resolution of conflicts. A bureaucratized executive increasingly designed programs of general legislation, rather than simply producing piecemeal local and personal acts to order. The history of company, property, and trusts statutes further shows how Parliament came to supervise and technically maintain the thickets of private law through "legislative maintenance." The history of revenue policies also reveals how the official state enlarged in scope during this period of reform.

Within the common law itself, Lord Mansfield and Lord Kenyon drew from Chancery procedures in their modernization of the Court of King's Bench into an effective commercial court in the later eighteenth century. The arcane writs and pleading rules were 
replaced with summary analysis by the judge, simplifying forensic enquiry by use of objective doctrines framing key concepts of intention and action and so leaving little discretion to civil juries. This internal transformation of the common law may be even more important a reform than cross-vesting of Chancery and common law jurisdictions. Indeed, it is arguable that the procedural fusion wrought by the Judicature Acts ruined this evolving juristic experiment by infiltrating equitable procedures including free evidence into the common law and thereby wrecking the classicism and objectivism of the writ system, as well as corrupting equity with common law doctrines that subverted its subjectivist emphasis on conscience and presumptive fraud. If some lawyers thought it imperative to combine law and equity for reasons of administrative convenience, others warned that this would destroy a useful partnership between different but complementary styles of law making and decision. Perhaps both factions were right. Lobban's study throws new light on these complex processes, but he tends to assume that right lay with the profusionist camp and does not perceive the downside of fusion. What is next needed is a study of the doctrinal interaction between the systems before and immediately after the Judicature Acts in order to judge what was gained and what was lost by that reform. Clues will be found in the history of the combined appellate system that replaced the common law system of review and retrial and the equitable appeal procedure.

One final point. Lobban makes tantalizing reference to the fusion experiments in the United States. Legal historians have long been aware of the importance of Kent and Story's treatises in joining legal and equitable doctrine into a common mold, and there are many areas such as bailment and partnership where these developments clearly had a deep influence on English law. It would be fascinating to look closely at American caselaw of the period in order to measure how far doctrinal fusion was effected at caselaw level and then to estimate how much of this radical fusion leaked across the Atlantic. $\frac{8}{}$

I have argued in this Comment that we need to integrate the history of all law reform and legal doctrinal change in the nineteenth century in order to deepen our understanding of the fusion debates. Procedural history is important in understanding fusion-but not all-important. This is a question of emphasis rather than critique. Lobban's history of fusion has massively improved our understanding of civil justice and his findings will stimulate further research and interpretation.

Joshua Getzler is a Fellow at St. Hugh's College, Oxford and a Lecturer in the Faculty of Law, Oxford University <joshua.getzler@law.ox.ac.uk>.

\section{Notes}

1. See Michael Lobban, "Preparing for Fusion: Reforming the Nineteenth-Century Court of Chancery. Parts I and II,"Law and History Review 22 (2004): 389-427, 565-99.

\footnotetext{
2. For the earlier history, see M. R. T. Macnair's magisterial study, The Law of Proof in Early Modern Equity (Berlin: Duncker \& Humblot, 1999).

3. F. W. Maitland, letter to M. M. Bigelow, 19 April 1906, in The Letters of Frederic William Maitland, ed. C. H. S. Fifoot (Cambridge, Mass.: Harvard University Press and the Selden Society, 1965), 372.

4. Patrick Polden, "Mingling the Waters: Personalities, Politics and the Making of the Supreme Court of
} 
Judicature," Cambridge Law Journal 61.3 (2002): 575-611 at 580-82.

5. P.P. 1818 (276) VI.

6. 6 Geo. IV, c. 16 , in 136 sections.

${ }_{7}^{7}$ Regulations in Bankruptcy (1801) 6 Vesey Junior 1.

8. See, e.g., Joseph White Moulton, The Chancery Practice of the State of New York, 3 vols., (New York: O. Halsted, 1829-32); John Greene Henderson, Chancery Practice (Chicago: T. H. Flood \& Co., 1904).

○2004 American Society for Legal History 